\title{
STRATEGI PEMASARAN PEMBIAYAAN WARUNG MIKRO BANK SYARIAH MANDIRI KC. KENDAL
}

\author{
Akhmad Nurasikin \\ Fakultas Agama Islam Universitas Wahid Hasyim \\ asikinnur12@gmail.com
}

\begin{abstract}
The development of Micro Small Enterprises (SMEs) annually increasing. This is due to the high interest of the community, especially the SMEs who want to start a business. One of the problems faced is the limited capital owned. Bank Syariah Mandiri (BSM) is present as a solution to answer the capital problems of SMEs by offering microfinance through Micro Stalls (Warung Mikro).

This study aims to find out how the implications of the marketing strategy are with the approach to the marketing mix (product, price, place and promotion) of BSM micro stalls and analyze their strengths and weaknesses.

Based on the results of research conducted by the author, that the marketing strategy carried out has positive implications for the progress of the business of its customers and increases the financing portfolio of Micro Stalls, BSM KC, Kendal. The advantages of the products include Principles and agreements in accordance with the Shari'ah, Limit of financing in accordance with micro segments, The process of applying for financing is relatively easy and fast, minor installments and fixed to maturity, business training and assistance programs for MSES, using an individual approach and ball pick up system and is located in a area that is relatively close to the micro segment business location. While the disadvantages of financing Micro Stalls, BSM KC, Kendal, among others; the lack of employees who master shari'ah transactions, inadequate facilities and promotions is still monotonous so it is less efficient.
\end{abstract}

Keywords: Marketing Strategy, Financing, Micro Stalls

\section{Abstrak}

Perkembangan Usaha Kecil Mikro (UKM) setiap tahunnya terus mengalami peningkatan. Hal ini disebabkan oleh tingginya minat masyarakat khususnya para pelaku UKM yang ingin memulai usaha. Salah satu masalah yang dihadapinya yaitu keterbatasan modal yang dimiliki. Bank Syariah Mandiri (BSM) hadir sebagai solusi untuk menjawab masalah permodalan pelaku UKM dengan menawarkan pembiayaan mikro melalui Warung Mikro.

Penelitian ini bertujuan untuk mengetahui bagaimana implikasi dari strategi pemasaran dengan pendekatan bauran pemasaran (produk, harga, tempat, dan promosi) warung mikro BSM dan menganalisis Keunggulan dan kelemahannya.

Berdasarkan hasil penelitian yang dilakukan penulis, bahwa strategi pemasaran yang dilakukan berimplikasi positif terhadap kemajuan usaha para nasabahnya dan meningkatkan portofolio pembiayaan warung Mikro BSM KC. Kendal. Adapun keunggulan produk yang dimiliki antara lain Berprinsip dan akad sesuai dengan syari'ah, Limit pembiayaan sesuai segemen mikro, Proses pengajuan pembiayaan relatif mudah dan cepat, angsuran ringan dan tetap hingga jatuh tempo, program pelatihan dan pendampingan usaha bagi UMK, menggunakan pendekatan perorangan dan sistem jemput bola dan terletak didaerah yang relatif dekat dengan lokasi usaha segmen mikro. Sedangkan kelemahan pembiayaan Warung Mikro BSM KC. Kendal antara lain; kurangnya pegawai yang menguasai transaksi syari'ah, fasilitas yang kurang memadai dan promosi masih monoton sehingga kurang efisien.

Kata Kunci: Strategi Pemasaran, Pembiayaan, Warung Mikro 


\section{PENDAHULUAN}

Kemunculan Perbankan syari'ah sebagai organisasi yang relatif baru menimbulkan tantangan besar. Sebagai lembaga keuangan syariah, Perbankan syari'ah harus berpegang teguh pada prinsip-prinsip syariah. Keimanan menjadi landasan atas keyakinan untuk mampu tumbuh dan berkembang. Masih banyak potensi nasabah yang belum terjangkau oleh perbankan syari'ah dan minimnya informasi masyarakat tentang perbankan syari'ah menjadi tantangan tersendiri bagi manajemen perbankan syari'ah untuk memperluas pasar hingga berbagai kalangan dan wilayah-wilayah pelosok. Perkembangan Usaha Kecil Mikro (UKM) setiap tahunnya terus mengalami peningkatan. Hal ini disebabkan oleh tingginya minat masyarakat khususnya para pelaku UKM yang ingin memulai usaha. Salah satu masalah yang dihadapinya yaitu keterbatasan modal yang dimiliki. Bank Syariah Mandiri (BSM) hadir sebagai solusi untuk menjawab masalah permodalan pelaku UKM.

Dengan banyaknya Lembaga Keuangan syariah (LKS), menjadikan posisi Bank Syari'ah Mandiri (BSM) sebagai salah satu LKS yang harus mampu bersaing. Walaupun dengan persaingan yang sangat ketat BSM mampu memperlihatkan eksistensinya sebagai LKS yang mampu bersaing dengan perbankan lain.

Hal ini mengharuskan manajemen melakukan strategi khusus untuk mempertahankan eksistensi dan keunggulan kompetitif yakni merujuk pada kemampuan sebuah organisasi untuk memformulasikan strategi yang menempatkannya pada suatu posisi yang menguntungkan. Keunggulan kompetitif juga berarti kumpulan strategi untuk menentukan keunggulan suatu 
perusahaan dari persaingan diantara perusahaan yang lain, ${ }^{1}$ yang dalam hal ini yaitu Persaingan antara BSM dengan lembaga keuangan lainnya. Melihat persaingan perbankan syariah yang sangat ketat, tidak menyurutkan semangat BSM untuk membuka kantor cabang (KC) di kabupaten Kendal. BSM KC. Kendal dan merupakan Bank Umum Syari'ah pertama yang membuka kantor cabang di Kabupaten Kendal, yakni di jalan Soekarno Hatta no. 325 Kendal. Kabupaten Kendal terletak di wilayah yang sebagian besar penduduknya bermata pencaharian dalam sektor mikro seperti petani tembakau, petani padi, petani tambak, warung kelontongan, industri rumah tangga, dan lain-lain sehingga layak untuk pengembangan kantor cabang.

BSM menawarkan berbagai macam produk pembiayaan yang mampu bersaing khususnya segmen mikro. Agar marketable dan kompetitif di pasar serta lebih memasyarakatkan BSM, maka fitur pembiayaan segmen mikro dituntut menarik dengan proses pembiayaan mudah, cepat, efektif, dan efesien. Pada tahun 2010 BSM meluncurkan produk pembiayaan mikro melalui Warung Mikro yang merupakan produk pembiayaan mikro unggulan di BSM. ${ }^{2}$

Keberhasilan ini tampaknya tidak lepas dari kemampuan rekayasa sosial dan entrepreneurship para pegawainya. Kemampuan rekayasa sosial berguna dalam perintisan dan pengembangan komunitas nasabah pembiayaan, supaya nasabah mampu melakukan kerjasama dan kemitraan untuk saling menguatkan usahanya. Dalam hal ini warung mikro BSM berperan sebagai fasilitator. Sedangkan kemampuan entrepreneurship menjadi penting untuk memberikan rekomendasi atas usulan bisnis nasabah, sehingga pembiayaan warung mikro BSM benar-benar mampu meningkatkan omset bisnis dan pendapatan nasabahnya. Peningkatan omset dan perkembangan pembiayaan warung mikro BSM yang sedemikian pesat tentunya menimbulkan persaingan

\footnotetext{
${ }^{1}$ David Hunger dan Thomas Wheelen, Manajemen Strategis, Yogyakarta: Penerbit Andi, 2003, hlm. 16

${ }^{2}$ Hasil wawancara dengan Bapak Hari Novianto Kepala Warung mikro Bank Syari'ah Mandiri , 06 Agustus 2012
} 
yang semakin ketat antara pembiayaan warung mikro dengan lembaga keuangan lain seperti BPRS, BMT, KJKS dan Unit Usaha Pembiayaan mikro lainnya. Tak kalah pentingnya, bagaimana manajemen Warung mikro BSM terus melakukan upaya peningkatan layanan yang memuaskan nasabah agar nasabah tidak berpindah ke lembaga keuangan lain.

Penelitian ini dilakukan untuk menganalisa dan mengetahui sejauh mana strategi pemasaran yang dilakukan oleh Warung Mikro BSM Cabang Kendal, bagaimana keunggulan dan kelemahan strategi pemasaran yang dilakukan Warung Mikro BSM KC Kendal dan Implikasinya terhadap pertumbuhan pembiayaan dan perkembangan usaha yang rasakan oleh nasabah BSM KC. Kendal. Penelitian ini menggunakan metode penelitian lapangan (field research) yaitu sebuah penelitian yang dilaksanakan secara intensif dan terperinci terhadap obyek yang diinginkan dengan mempelajari data-data yang tersedia. Adapun yang menjadi obyek atau sumber diperolehnya data/keterangan yang dapat memperkuat keakuratan penelitian adalah manajemen dan nasabah Warung Mikro BSM KC. Kendal. Dalam penelitian ini metode pengumpulan data yang digunakan adalah observasi, interview dan dokumentatif. Sedangkan metode analisis yang digunakan adalah analisis deskriptif analitik. Deskriptif adalah metode yang bertumpu pada pencarian fakta-fakta dengan interpretasi yang tepat ${ }^{3}$ sehingga gambaran dan pembahasan menjadi jelas dan gamblang. Sedangkan analitik adalah cara untuk menguraikan dan menganalisa data dengan cermat, tepat dan terarah.

\section{Strategi Pemasaran}

Menurut Kamus Besar Bahasa Indonesia (KBBI) Strategi berarti rencana yang cermat mengenai kegiatan untuk mencapai sasaran khusus ${ }^{4}$, sedangkan Pemasaran berarti proses, cara, perbuatan memasarkan suatu barang

\footnotetext{
${ }^{3}$ M. Nazir, Metode Penelitian, Jakarta: Ghalia Indonesia, 1988, hlm. 63

${ }^{4}$ Departemen Pendidikan Nasional, Kamus Besar Bahasa Indonesia: Pusat Bahasa, Jakarta: Gramedia Pustaka Utama, 2012, hlm. 1340
} 
dagangan. ${ }^{5}$ Menurut Kamus Umum Bahasa Indonesia, strategi adalah ilmu siasat perang atau akal (tipu muslihat) untuk mencapai suatu maksud. ${ }^{6}$ Strategi adalah penetapan tujuan jangka panjang yang dasar dari suatu organisasi, dan pemilihan alternatif tindakan dan alokasi sumber daya yang diperlukan untuk mencapai tujuan tersebut. ${ }^{7}$ Pemasaran adalah proses perencanaan, pemikiran dan pelaksanaan konsepsi, pricing, promosi serta pendistribusian barang atau jasa dalam menciptakan pertukaran untuk mencapai tujuan atau sasaran perusahaan. ${ }^{8}$ Dalam istilah sehari-hari di artikan sebagai siasat perang dalam bisnis untuk mencapai tujuan perusahaan. Apabila kita definisikan ke dalam kompetisi bisnis di era 1990-an kita bisa mengatakan bahwa strategi adalah menetapkan arah kepada manajemen dalam arti orang tentang sumber daya didalam bisnis dan tentang bagaimana mengidentifikasikan kondisi yang memberikan keuntungan terbaik untuk membantu memenangkan persaingan didalam pasar. Dengan kata lain, definisi strategi mengandung dua komponen yaitu: future intentions atau tujuan jangka panjang dan competitive advantage atau keunggulan bersaing. ${ }^{9}$

Dalam manajemen strategis yang baru, Mintzberg mengemukakan 5P yang sama artinya dengan strategi, yaitu perencanaan (plan), pola (patern), posisi (position), prespektif (prespectife), dan permainan atau taktik (play). Strategi juga menyangkut segala sesuatu yang telah dilakukan di masa lampau, misalnya pola-pola perilaku bisnis yang telah dilakukan di masa lampau. Menurut Mintzberg strategi adalah pola, yang selanjutnya disebut sebagai intended strategy, karena belum terlaksana dan berorientasi kemasa depan. Atau disebut juga sebagai realized strategy karena telah dilakukan oleh perusahaan. Menurutnya strategi adalah suatu maneuver tertentu untuk

\footnotetext{
5 Ibid, hlm. 1027

${ }^{6}$ W.J.S Poerwadarminta, Kamus Umum Bahasa Indonesia, cet. 6, Jakarta: Balai pustaka, 1983, hlm. 956.

${ }^{7}$ Kashmir, Kewirausahaan, Jakarta: PT Raja Grafindo, 2006, hlm. 171.

${ }^{8}$ Faisal Akbar, Strategi Pemasaran BMT Al Ikhlas Yogyakarta, Skripsi Ekonomi Islam, Yogyakarta, Perpustakaan UII, 2010, hlm. 16.

${ }^{9}$ Crown Dirgantoro, Manajemen Stratejik, Jakarta: PT Grasindo, 2001, hlm. 5.
} 
memperdaya lawan atau pesaing. Suatu merek misalnya meluncurkan merek kedua agar posisinya tetap kukuh dan tidak tersentuh, karena merek-merek pesaing akan sibuk berperang melawan merek kedua tadi. ${ }^{10}$

Definisi pemasaran menurut William J. Stanton adalah suatu sistem keseluruhan dari kegiatan-kegiatan usaha yang ditujukan untuk merencanakan, menentukan harga, mempromosikan dan mendistribusikan barang dan jasa yang dapat memuaskan kebutuhan baik kepada pembeli yang ada maupun pembeli potensial. ${ }^{11}$ Menurut Kottler, Pemasaran merupakan salah satu kegiatan yang dilakukan oleh perusahaan dalam usaha untuk mempertahankan kelangsungan hidup perusahaan. Pemasaran mempunyai arti penting karena keberhasilan suatu perusahaan dalam mencapai tujuan tergantung pada berhasil atau tidaknya seorang manajer pemasaran dalam memahami keinginan dan kebutuhan konsumen. Dengan demikian konsumen bisa puas dengan hasil produksi serta pelayanan yang diberikan. ${ }^{12}$ Sedangkan Menurut Kashmir secara umum pengertian pemasaran bank adalah suatu proses untuk menciptakan dan mempertukarkan produk atau jasa bank yang ditujukan untuk memenuhi kebutuhan dan keinginan nasabah dengan cara memberikan kepuasan. $^{13}$

Menurut Mudrajat Kuncoro adalah strategi pemasaran untuk mencapai tujuan yaitu langkah-langkah segmentasi pasar, menetapkan posisi pasar, menetapkan strategi menembus pasar dan mengembangkan bauran pemasaran. ${ }^{14}$ Pemasaran berasal dari kenyataan bahwa manusia memilih kebutuhan dan keinginan pemilihan produk ditentukan oleh konsep nilai,

\footnotetext{
${ }^{10}$ Suryana, Kewirausahaan, Jakarta: PT Salemba Emban Patria, 2001, hlm. 129-130.

${ }^{11}$ Bashu swasta dhammesta, Manajemen Pemasaran: Analisa Perilaku Konsumen, Yogyakarta: BPFE, 2000, hlm. 4.

${ }^{12}$ Phillip Kottler, Manajemen Pemasaran Analisis, Perencanaan, Implementasi, dan Kontrol, Jakarta : Prehallindo, 2002, hlm. 125

${ }^{13}$ Kasmir, Bank dan Lembaga Keuangan Lainnya, Jakarta: Raja Grafindo Persada, 2002, hlm. 66 2002, hlm. 66

${ }^{14}$ Mudrajat Kuncoro, Manajemen Perbankan, Teori dan Aplikasi, Yogyakarta: BPFE,
} 
biaya, kepuasan. Dimana hal ini disebabkan karena banyak produk yang tepat memenuhi suatu kebutuhan. Dapat dikatakan pula bahwa pemasaran terdiri dari serangkaian prinsip untuk memilih pasar sasaran, mengevaluasi kebutuhan konsumen, mengembangkan barang dan jasa, pemuas keinginan, memberikan nilai kepada konsumen dan bagi perusahaan. Konsep pemasaran merupakan sebuah falsafah bisnis yang menyatakan bahwa pemuasan kebutuhan konsumen menyebabkan kelangsungan hidup perusahaan. Dalam perkembangannya strategi pemasaran modern dapat dideskripsikan melalui 3 kunci antara lain Segmentasi, Targeting, Positioning

Untuk membidik target sesuai sasaran pemasaran dan tidak meninggalkan kaidah-kaidah islami guna menunjukan hasil yang memuaskan pada penjualan dan laba maka ada beberapa kiat perusahaan dalam membangun citranya. Perusahaan dalam memproduksi barang tidak membohongi pelanggan, baik menyangkut besaran (kuantitas) maupun kualitas. Ibnu Umar r.a meriwayatkan sebuah hadits bahwa seseorang menemui Nabi dan berkata bahwa ia selalu dicurangi dalam pembelian. Nabi bersabda kepadanya agar pada waktu membeli (sesuatu) mengatakan tidak ada penipuan (HR. Muttafaqun 'Alaih) ${ }^{15}$

Pelanggan yang tidak sanggup membayar kontan diberi tempo untuk membayar angsuran. Selanjutnya pengampunan (bila mungkin) hendaknya diberikan jika ia benar-benar tidak sanggup membayar. Perusahaan harus menjauhi sumpah yang berlebihan dalam menjual suatu barang. Dewasa ini banyak pedagang mencoba meyakinkan calon pembelinya. Dengan melakukan sumpah palsu. Islam melarang semua transaksi bisnis menggunakan sumpah palsu yang diucapkan oleh para pengusaha, Abu Hurairah berkata, Aku pernah mendengar Rasulullah SAW bersabda: Bersumpah (yang dilakukan penjual) mungkin meyakinkan pembeli bahwa barang (yang ditawarkan kepadanya

${ }^{15}$ Ibnu Hajar al-asqalani, Bulugul marảm min adillah al-ahkảm, Al-Hafidz Abdul Rosyad Siddiq, Terjemahan Lengkap Bulugul marảm, Jakarta: Akbar Media Eka Sarana, 2009, hlm. 368 . 
adalah barang) bagus tetapi akan melenyapkan berkah. (HR. Bukhari dan Muslim) $)^{16}$

Hanya dengan pemuasan bersama, antara penjual dan pembeli dalam bertransaksi dengan suatu usulan dan penerimaan, penjualan dalam Al-Quran dijelaskan; Hai orang-orang yang beriman, janganlah kamu saling memakan harta sesamamu dengan jalan yang batil, kecuali dengan jalan perniagaan yang berlaku dengan suka sama suka di antara kamu dan janganlah kamu membunuh dirimu, Sesungguhnya Allah adalah Maha Penyayang kepadamu. (QS. An-Nisa': 29) ${ }^{17}$

Adapun hal yang perlu dipertimbangankan dalam strategi pemasaran Paling tidak terdapat dua variabel yang harus menjadi bahan pertimbangan dalam melakukan strategi pemasaran, yaitu: Segmentasi pasar, Anggaran pemasaran, Waktu (time table), Bauran pemasaran (marketing mix). Bauran Pemasaran (Marketing Mix) merupakan komponen-komponen yang di manfaatkan oleh manajemen di dalam kegiatan penjualan, menurut Hermawan Kertajaya bahwa pemasaran (marketing mix) terdiri dari 4P (Product, Price, Place, Promotion). ${ }^{18}$ Produk atau jasa yang dibuat harus memperhatikan nilai kehalalan, bermutu, bermanfaat dan berhubungan dengan kehidupan menusia. Melakukan jual beli yang mengandung unsur tidak jelas (gharar) terhadap suatu produk akan menimbulkan potensi terjadinya penipuan dan ketidakadilan terhadap salah satu pihak. Rasulullah SAW melarang kita untuk transaksi terhadap suatu produk yang mengandung unsur gharar. Sabda Rasullah SAW: Sesungguhnya Nabi SAW. Melarang jual beli dengan lemparan batu dan jual beli yang samar(gharar) (H.R Muslim). ${ }^{19}$ Hakim bin Hizam bertanya: Ya

16 Abu Zakaria, Riyadus sảlihỉn, Achmad Sunaryo, Terjemahan Riyadus sảlihỉn, Jakarta: Pustaka Amani, 1999, hlm. 547

${ }^{17}$ Departemen Agama RI, Al Qur'an dan Tafsirnya:Edisi Yang Disempurnakan, Jakarta: Departemen Agama RI, Cet. Ke-3, 2009, hlm. 478

${ }^{18}$ Amin Abdullah, Strategi Pemasaran Asuransi Syariah, Jakarta: PT. Grasindo, 2007, hlm. 59-62

${ }^{19}$ Hamzah Ya'kub, Kode Etik Dagang Menurut Islam, Bandung: CV. Diponegoro, Cet. Pertama, 1984, hlm. 133 
Rasulullah! Sesungguhnya saya membeli beberapa barang dagangan, maka apakah yang halal bagiku dari padanya, dan apa pula yang haram bagiku? Nabi Menjawab: Apabila engkau membeli sesuatu, maka janganlah engkau jual, sebelum engkau memegangnya (menerimanya) (HR, Ahmad). ${ }^{20}$

Kualitas dari suatu produk(product) harus menjadi perhatian utama dimana barang yang dijual harus jelas dan baik kualitasnya, agar calon pembeli dapat menilai dengan mudah terhadap produk tersebut. Dengan demikian, pengertian produk dalam ekonomi syariah haruslah memenuhi standarisasi mutu, berdaya guna, mudah di pakai, indah dan memiliki daya tarik.

Penentuan harga(price) dalam ekonomi syariah didasarkan atas mekanisme pasar, yakni harga ditentukan berdasarkan kekuatan permintaan dan penawaran atas azas sukarela (an'taradhiin). Sehingga tidak ada satu pihak pun yang teraniaya atau terzalimi. Dengan syarat kedua belah pihak yang bertransaksi mengetahui mengenai produk dan harga yang dipasarkan.

Penentuan tempat(place) yang mudah terjangkau dan dilihat akan memudahkan bagi konsumen untuk mengetahui, mengamati dan memahami dari suatu produk atau jasa yang ditawarkan. Penentuan tempat didasarkan atas jenis usaha atau produk yang diciptakan. Penempatan suatu produk atau jasa sangat mempengaruhi tingkat harga, semakin representative suatu tempat maka berdampak akan semakin tinggi nilai suatu produk.

Promosi(promotion) dalam sistem ekonomi syariah harus memperhatikan nilai-nilai kejujuran dan menjauhi penipuan. Media atau sarana dan metode yang digunakan harus sesuai dengan syariah. Paling tidak ada empat macam sarana promosi yang dapat digunakan oleh setiap perusahaan dalam mempromosikan produknya antara lain;

${ }^{20}$ Ibid, hlm. 93 
1. Periklanan (advertising) dengan tujuan untuk pemberitahuan tentang segala sesuatu yang berkaitan dengan produk yang dimiliki oleh suatu perusahaan, untuk perhatian dan minat pelanggan baru dengan harapan akan memperoleh daya tarik dari para calon pelanggan dan mempengaruhi pelanggan pesaing agar berpindah keproduk dari perusahaan yang mengiklankan.

2. Promosi Penjualan (sales promotion) dengan tujuan meningkatkan penjualan atau meningkatkan jumlah pelanggan,

3. Publisitas (publicity) merupakan kegiatan promosi untuk memancing pelanggan melalui kegiatan, seperti pameran, bakti sosial, serta kegiatan lainnya,

4. Penjualan pribadi (personal selling) dilakukan oleh marketing dengan cara door to door.

\section{Pembiayaan Warung Mikro}

Pembiayaan Warung Mikro merupakan fasilitas pembiayaan yang diperuntukkan bagi masyarakat yang memiliki Usaha Mikro Kecil dan Menengah (UMKM). ${ }^{21}$ Akad perjanjian yang digunakan oleh BSM ialah akad jual beli(murabahah). Keuntungan pembiayaan mikro dengan akad murabahah berbentuk marjin penjualan yang sudah termasuk harga penjualan. Keuntungan tersebut sewajarnya dapat dinegosiasikan antara pihak bank dan nasabah. Sedangkan Pembayaran harga barang dapat dilakukan secara angsuran. Dalam pembayaan murabahah memungkinkan adanya jaminan, karena sifat dari pembiayaan murabahah merupakan jual beli yang pembayarannya tidak dilakukan secara tunai. Sehingga bank syari'ah memberlakukan prinsip kehatihatian dengan mengenakan jaminan kepada nasabah.

\footnotetext{
${ }^{21}$ Hasil Wawancara dengan bapak Hari Novianto, pada hari sabtu, tanggal 7 Mei 2013
} 
Menurut istilah fiqih dalam kamus Istilah fiqih dijelaskan bahwa murabahah adalah bentuk jual beli barang dengan tambahan harga (Cost Plus) atas harga pembelian yang pertama secara jujur. Dengan Murabahah ini, orang pada hakikatnya ingin mengubah bentuk bisnisnya dari kegiatan pinjammeminjam menjadi transaksi jual beli. ${ }^{22}$ Murabahah adalah salah satu bentuk jual beli yang dibenarkan oleh syari'at islam dan merupakan implementasi dari muamalah tijariyah (interaksi bisnis). Adapun dasar hukum yang membolehkan jual beli murabahah adalah Al Qur'an surat Al Baqarah ayat 275 dan Surat An Nisa' ayat 29. Dan Allah telah menghalalakan jual beli dan mengharamkan riba.(QS. Al Baqarah: 275) ${ }^{23}$

Hai orang-orang yang beriman, janganlah kamu saling memakan harta sesamamu dengan jalan yang batil, kecuali dengan jalan perniagaan yang berlaku dengan suka sama-suka di antara kamu. dan janganlah kamu membunuh dirimu, Sesungguhnya Allah adalah Maha Penyayang kepadamu. (QS. An-Nisa': 29) ${ }^{24}$

Ibnu Majjah juga meriwayatkan sebuah Hadits; Nabi bersabda ada tiga hal yang mengandung berkah: jual beli tidak secara tunai, muqaradhah(mudharabah), dan mencampur gandum dengan jewawut untuk keperluan rumah tangga, bukan untuk dijual. (HR. Ibnu Majah).

Ketentuan yang harus dipenuhi dalam jual beli murabahah meliputi Jual beli murabahah harus dilakukan atas barang yang telah dimiliki/hak kepemilikan telah berada ditangan penjual. Adanya kejelasan informasi mengenai besarnya modal (harga pembelian) dan biaya-biaya lain yang lazim dikeluarkan dalam jual beli pada suatu komoditi, semuanya harus diketahui oleh pembeli saat akan dan ini merupakan salah satu syarat sah murabahah.

${ }^{22}$ M. Abdul Mujieb, Kamus Istilah fiqh, Jakarta: PT. Pustaka Firdaus, Cet. 1, 2001, hlm.

23 Loc.Cit, hlm. 256

${ }^{24}$ Ibid, hlm. 478 
Ada informasi yang jelas tentang keuntungan baik nominal maupun persentase sehingga diketahui oleh pembeli sebagai salah satu syarat murabahah. Konsep pembiayaan murabahah pada perbankan syari'ah muncul karena bank tidak memiliki barang yang diinginkan oleh nasabah, sehingga bank harus melakukan transaksi pembelian atas barang yang diinginkan nasabah kepada pihak lainnya yang disebut sebagai supplier. Dengan demikian, bank bertindak selaku penjual disatu sisi, dan disisi lain bertindak selaku pembeli. Kemudian menjualnya kembali kepada nasabah bank tersebut yang bertindak sebagai pembeli dengan harga yang disesuaikan yakni harga beli ditambah margin yang disepakati. Dibawah ini penulis gambarkan skema transaksi murabahah diperbankan syari'ah;

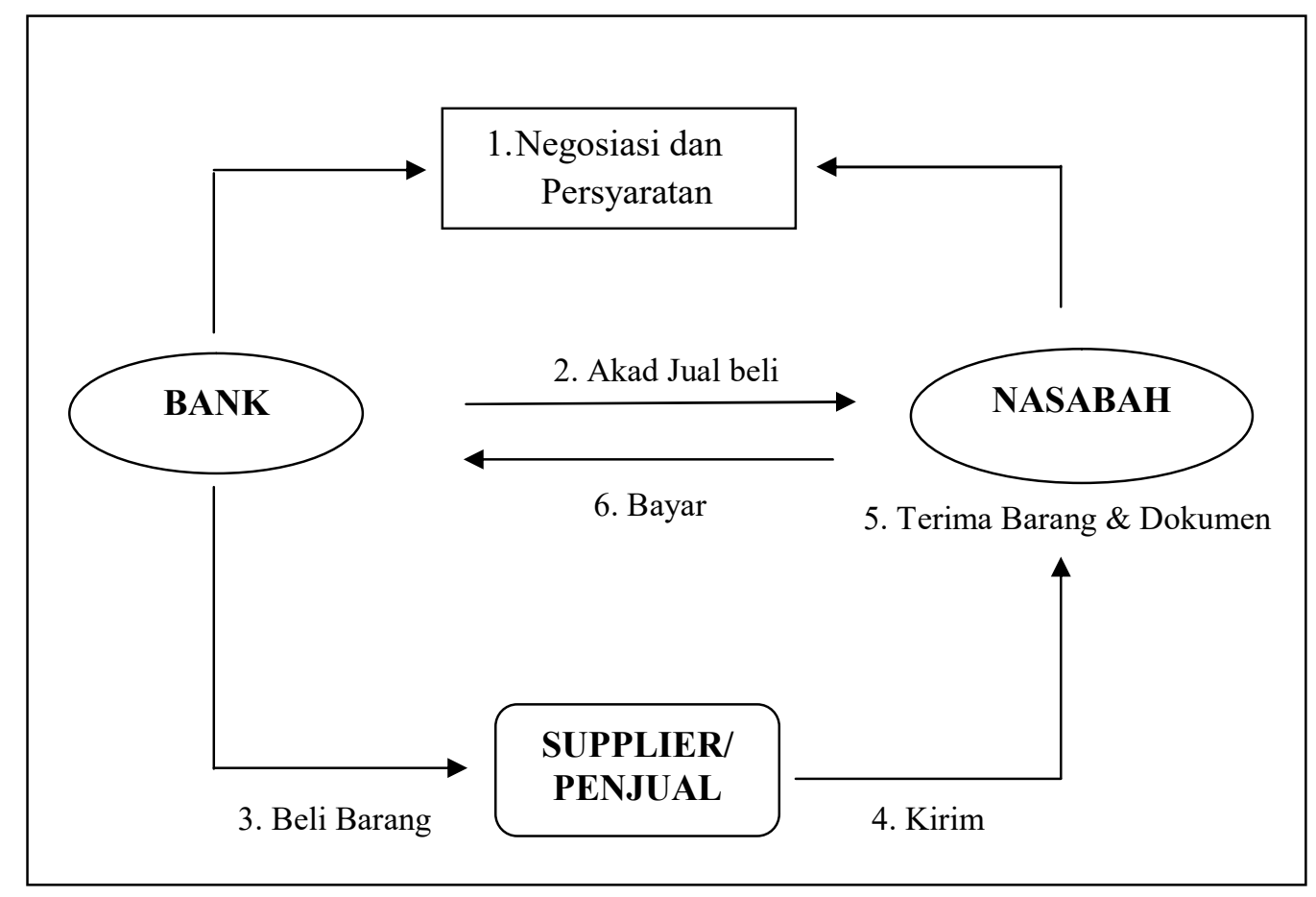

Sumber: PT. Bank Syariah Mandiri KC. Kendal

Berdasarkan kuesioner yang penulis ajukan kepada beberapa nasabah, sebagian besar menyatakan terbantu dengan adanya produk pembiayaan 
warung mikro BSM KC. Kendal khususnya program KUR. Namun demikian mereka masih merasa kurang nyaman dengan syarat pengajuan pengajuan pembiayaan yang relatif rumit. ${ }^{25}$

Nasabah merasa terbantu dengan adanya jangka waktu angsuran minimal 12 bulan ( 1 tahun) sampai 48 bulan ( 4 tahun) sesuai plafond yang diinginkan nasabah. Pasalnya, mereka dapat memilih nominal angsuran yang telah tercantum didalam brosur sesuai dengan kemampuan angsuran atau disesuaikan dengan penghasilan nasabah. Walaupun dalam jangka waktu yang telah ditentukan nasabah belum bisa melunasi angsuran, mereka masih mendapat keringanan dengan rescedulling ataupun Restrukturing angsuran. Dan jika nasabah melunasi pinjaman atau menyelesaikan angsuran sebelum jatuh tempo, maka nasabah tidak akan dikenai biaya penalti namun tetap dikenai biaya administasi sebesar Rp 100.000,00. Berbeda dengan Ibu Retno Puji Astuti yang merupakan nasabah dari Semarang, dia mengatakan bahwa alasan mengapa meminjam uang di Warung Mikro BSM KC. Kendal yaitu karena, beliau dekat dengan salah satu pegawai warung mikro sehingga syarat pengajuan pinjaman dipermudah tanpa mengabaikan Standar Operasional Pembiayaan(SOP) di BSM.

Menurut bapak Imam Santoso yang merupakan pedagang sembako, sangat terbantu dengan adanya pembiayaan warung mikro BSM KC. Kendal, munurut beliau dengan adanya Pembiayaan warung Mikro BSM KC. Kendal ini memberi keuntungan 2 sekaligus, yakni meningktnya omset karena mendapat tambahan modal, persyaratan yang tidak terlalu rumit dan relatif murah biaya administrasinya serta mudah dan terjangkau dalam mengangsur pinjamananya. Tetapi, menurut salah satu nasabah yang bekerja sebagai pedagang di Pasar sore kaliwungu bahwa dengan adanya warung mikro BSM KC. Kendal, sangat terbantu dengan letak outlet yang dekat dengan tempat usaha, sehingga mempermudah dalam membayar angsuran pinjaman.

\footnotetext{
${ }^{25}$ Hasil pengajuan Kuesioner kepada nasabah pada hari senin-jum’at, 20-24 Mei 2013.
} 
Menurut Intan Komala Dewi, sebenarnya masalah lokasi tidak menjadi alasan yang vital untuk mengajukan pembiayaan diwarung mikro, tetapi dia berorientasi pada keuntungan dari pembiyaan diwarung mikro BSM KC. Kendal lebih baik dibanding dengan lembaga keuangan yang ada di Kendal. Namun demikian, banyak nasabah yang meminjam uang untuk menambah modal usaha dengan tidak berorientasi pada letak outlet yang dekat dengan tempat dimana mereka berdagang. Selain itu, bapak Bakri yang merupakan nasabah dari kecamatan boja, kab. Kendal yang mengajukan pembiayaan warung mikro bukan karena strategi harga, promosi maupun tempat yang yang menarik tetapi Karena kedekatan beliau dengan salah satu pegawai warung mikro BSM KC. Kendal.

\section{PEMBAHASAN}

Warung mikro adalah layanan pembiayaan di kantor cabang dan cabang pembantu untuk nasabah kategori mikro. ${ }^{26}$ Plafon maksimum yang diberikan kepada nasabah melalui warung mikro adalah Rp 100 juta sesuai dengan rata-rata maksimum kebutuhan usaha mikro saat ini. Akad yang digunakan pada produk pembiayaan Warung mikro ialah akad Murabahah. Implikasi dari akad Murabahah mengharuskan adanya penjual, pembeli dan barang yang dijual. Sebagaimana kita ketahui dalam skim murabahah fungsi bank adalah sebagai penjual barang untuk kepentingan nasabah dengan cara membeli barang yang dibutuhkan nasabah dan kemudian menjualnya kembali kepada nasabah dengan harga jual yang setara dengan harga beli ditambah keuntungan bank dan bank harus memberitahukan secara jujur harga pokok barang berikut biaya yang diperlukan dan menyampaikan semua hal yang berkaitan dengan pembelian barang kepada nasabah.

Pada aplikasinya BSM KC Kendal menggunakan media akad wakalah dengan memberikan kuasa kepada nasabah untuk membeli barang tersebut. Dengan adanya akad wakalah maka bank sepenuhnya menyerahkan dana

\footnotetext{
${ }^{26}$ www. syari'ahmandiri.co.id, Diakses pada tanggal 5 Oktober 2012
} 
tersebut kepada nasabah untuk membeli barang-barang yang dibutuhkan oleh nasabah. Walaupun bank telah menggunakan akad wakalah kepada nasabah, namun bank akan tetap melakukan pengawasan terhadap barang-barang yang dibeli oleh nasabah agar tidak keluar dari koridor yang ada dalam fatwa DSNMUI Nomor 10/DSN-MUI/IV/2000 dan syari'at islam. Hal ini dilakukan untuk mencegah nasabah melakukan transaksi yang dilarang, misalnya menggunakan dana pembiayaan untuk membeli barang-barang yang termasuk barang haram.

Dari beberapa teori pemasaran yang telah dijelaskan sebelumnya, dalam penelitian ini, penulis menggunakan pendekatan teori bauran pemasaran (Marketing Mix) yang diterdiri dari $4 \mathrm{P}$ antara lain Produk (Product), Harga (Price), Tempat (Place) dan Promosi (Promosion).

\section{Produk (Product)}

Untuk melakukan kegiatan pemasaran, Warung Mikro BSM KC. Kendal mempunyai strategi pemasaran, yakni dengan melakukan strategi produk dengan Menentukan motto. Agar nasabah mampu memahami maksud visi dan misi yang ingin dicapai BSM dalam melayani masyarakat, maka Warung Mikro juga memakai moto yang sama, yakni; Lebih Adil dan Menentramkan, Menciptakan merk, yakni Pembiayaan Usaha Mikro Tunas (PUM-Tunas), PUM-Madya, PUM-Utama dengan mempertimbangkan faktor-faktor berikut; Mudah diingat, Terkesan modern, Memiliki arti (dalam arti positif).

2. Harga (Price).

Harga ditentukan berdasarkan fitur produk yang telah disebutkan pada bab sebelumnya. Karena akad yang di gunakan dalam transaksi ini yaitu akad murabahah, maka dalam pelunasan pinjaman yaitu dengan cara diangsur. Adapun jangka waktu angsuran minimal 12 bulan (1 tahun) sampai 48 bulan (4 tahun) sesuai plafond yang diinginkan nasabah. Strategi ini 
bertujuan untuk mengukur kemampuan nasabah dalam melunasi pinjaman dan mempermudah serta meringankan nasabah dalam melunasi angsuran sesuai kemampuan nasabah. Selain dengan strategi angsuran yang ringan, juga dengan angsuran tetap sampai dengan jatuh tempo. Disamping itu, jika nasabah melunasi pinjaman atau menyelesaikan angsuran sebelum jatuh tempo, maka nasabah tidak akan dikenai biaya penalti namun tetap dikenai biaya administasi sebesar Rp. 100,000,-. Adapun Produk yang paling diminati selain program KUR yaitu Produk Pembiayaan Mikro (PUM) Madya, karena sebagian besar nasabah yang mengajukan pembiayaan merupakan nasabah yang ingin mengembangkan usahanya.

3. Tempat (Place)

Dalam upaya Warung Mikro BSM KC. Kendal melayani konsumen tepat waktu dan tepat sasaran. Keterlambatan dalam penyaluran informasi dapat mengakibatkan Warung Mikro BSM KC. Kendal kehilangan waktu dan kualitas jasa serta diambilnya kesempatan oleh para pesaing. Oleh karena itu, Warung Mikro BSM KC. Kendal menggunakan sistem jemput bola, yakni petugas langsung mendatangi nasabah di tempat tinggal atau ditempat usaha sehingga lebih leluasa dalam menjelaskan dan memasarkan produk Warung Mikro BSM KC. Kendal kepada calon nasabah. Berdasarkan pengamatan penulis, strategi tempat yang dilakukan Warung Mikro BSM KC. Kendal kurang baik, karena walaupun lokasi Outlet dekat dengan pasar-pasar di kecamatan Kaliwungu, Weleri dan Pasar Kendal, namun sebagian besar nasabah berasal dari masyarakat yang jauh dari lokasi kantor.

\section{Promosi (Promosion).}

Salah satu tujuan promosi Warung Mikro BSM KC. Kendal ialah memberikan informasi terkait jenis produk yang ditawarkan dan berusaha menarik calon konsumen yang baru. Ada empat macam sarana promosi 
yang digunakan Warung Mikro BSM KC. Kendal dalam mempromosikan produknya yakni melalui iklan spanduk di jalan, tempat, atau lokasi yang strategis dan melalui brosur yang disebarkan di setiap Sales outlet; pemberian cindera mata serta kenang-kenangan yang lainnya pada konsumen yang loyal; memancing calon nasabah melalui kegiatan pengajian dimasjid, mushola maupun majelis pengajian dan sponsor dalam kegiatan bakti sosial dan Penjualan pribadi oleh marketing dengan cara door to door.

Peneliti dapat memberikan gambaran bahwa Operasional produk pembiayaan warung mikro BSM KC. Kendal sudah sesuai dengan syari'at islam. Walaupun dengan akad wakalah sebagai tambahan tentunya hal ini akan sedikit menimbulkan pertanyaan apakah bank syari'ah sudah menjalankan operasionalnya sesuai dengan prinsip-prinsip syari'ah. Akad wakalah membuat persepsi masyarakat bahwa tidak ada bedanya dengan bank konvensional, karena pada praktiknya akan menimbulkan persamaan teknis akad kredit di Bank Konvensional. Akad murabahah pada produk pembiayaan warung mikro BSM KC. Kendal yang seharusnya bertindak sebagai penyedia barang, terkesan tidak mau dipusingkan dengan langkah-langkah pembelian barang. Selain itu dalam aplikasinya, akad jual beli murabahah dilakukan sebelum barang secara prinsip menjadi milik warung mikro. Hal ini tentunya tidak sesuai dengan ketentuan fatwa MUI No.04/DSN-MUI/IV/2000 tanggal 1 April 2000 yang menetapkan bahwa jika bank hendak mewakilkan ke nasabah untuk membeli barang dari pihak ketiga, maka akad jual beli murabahah harus dilakukan setelah barang secara prinsip milik bank. Masalah ini tentunya harus benarbenar diperhatikan oleh bank-bank syari'ah yang ada karena masalah ini bisa berpotensi menurunkan citra bank syari'ah.

Mengenai hal ini, Dewan Pengawas Syari'ah (DPS) menganggap masih berada pada didalam koridor syari'ah, karena ketidaksesuaian itu masih berada ditataran teknis dan tidak masuk kedalam wilayah prinsip. Oleh karena itu produk pembiayaan warung mikro BSM KC. Kendal masih sesuai dengan prinsip syari'ah dan layak adanya. 
Salah satu tujuan promosi Warung Mikro BSM KC. Kendal adalah menginformasikan segala jenis produk yang ditawarkan dan berusaha menarik calon konsumen yang baru. Tetapi dalam praktiknya media melalui brosur tidaklah efisien, karena jarang nasabah membaca brosur-brosur yang telah disebar oleh marketer warung mikro BSM KC. Kendal. Justru yang menurut pengamatan penulis nasabah mau mengajukan pembiayaan diwarung mikro karena nasabah mengenal dekat dengan salah satu pegawai warung mikro BSM KC. Kendal.

Dengan menggunakan strategi pemasaran Warung Mikro BSM KC. Kendal yang telah penulis jelaskan, mempunyai implikasi yang cukup baik terhadap jumlah nasabah maupun jumlah pencairan pembiayaan Warung Mikro BSM KC. Kendal yang baru berjalan dalam kurun waktu dua tahun. Berdasarkan wawancara, Sampai bulan April 2013 ini Warung Mikro sudah mencatat nasabah sebanyak 169 orang baik dari nasabah yang berasal dari Kendal dan sekitarnya. Adapun pencairan pembiayaan Warung Mikro sampai bulan April 2013 telah mencapai Rp 3.854.193.346,03.

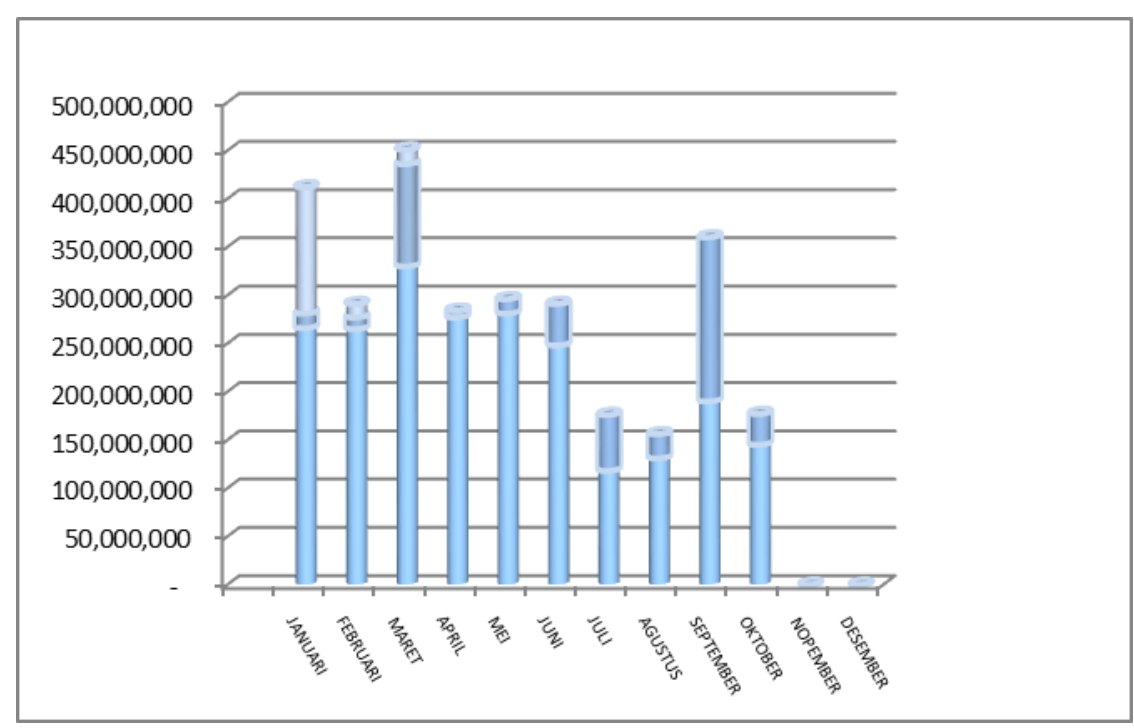

Sumber: Warung Mikro BSM KC. Kendal

Pencairan selama tahun 2012 mengalami pasang surut. Hal ini terjadi karena dipengaruhi adanya beberapa faktor, salah satunya yaitu keluar masuknya pegawai warung mikro sehingga menyebabkan menurunnya kinerja 
Warung Mikro. Tetapi jika dilihat dari segi jumlah nasabah setiap bulan banyak mengalami peningkatan.

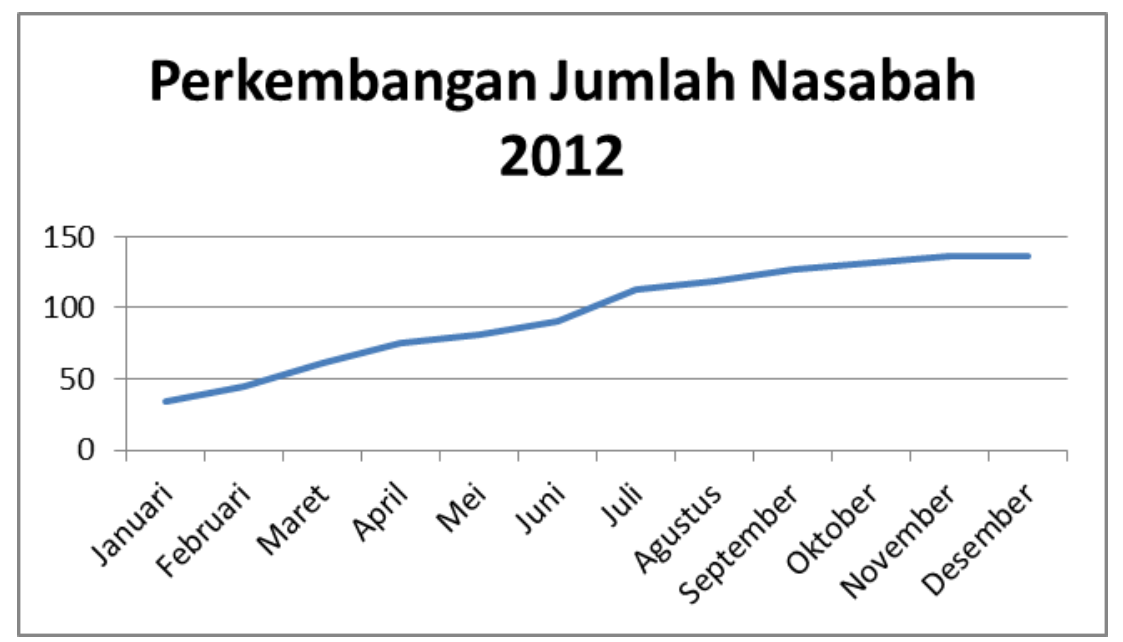

Sumber: Warung Mikro BSM Kendal SO Kaliwungu

Dilihat dari sisi produk warung mikro BSM memiliki keunggulan kompetitif yaitu Berprinsip dan akad sesuai dengan syari'ah karena produk pembiayaan Warung Mikro merupakan produk yang menggunakan akad-akad yang sesuai dengan syari'ah Islam, limit pembiayaan mulai dari Rp 2000,000,sampai Rp 100,000,000,- merupakan plafond yang dikhususkan untuk pelaku UMKM, Proses pengajuan pembiayaan yang relatif mudah dan cepat yakni maksimal tiga hari sejak persyaratan lengkap.

Dalam meningkatkan keunggulan kompetitif strategi harga yang dilakukan warung mikro mikro BSM Angsuran ringan dan tetap hingga jatuh tempo serta disesuaikan dengan price dari record penjualan atas usaha yang dijalankan Nasabah, Program pelatihan dan pendampingan usaha bagi UMK, Menggunakan pendekatan perorangan dan sistem jemput bola. Dilihat dari segi tempat, Warung Mikro BSM KC. Kendal terletak didaerah yang relatif dekat dengan lokasi usaha segmen mikro.

Walaupun Warung Mikro Bank Syari'ah Mandiri (BSM) memiliki sederet kelebihan, namun Warung Mikro BSM KC. Kendal tetap memiliki kelemahan-kelemahan, antara lain: Lemahnya Pengetahuan mengenai Ekonomi Syari'ah khususnya Perbankan syari'ah menyebabkan pegawai Warung Mikro 
BSM KC. Kendal kurang menguasai akad-akad yang digunakan sehingga jika pertanyaan dari nasabah terkait akad-akad syari'ah, maka mereka tidak bisa memeberikan jawaban yang memuaskan nasabah. Disamping itu pada aplikasi akad murabahah masih terkesan sama dengan cara memperoleh keuntungan melalui sistem bunga. Hal ini bisa dilihat dari perkiraan angsuran yang telah penulis paparkan. Dilihat dari segi operasional pengajuan pembiayaan juga tidak jauh berbeda dengan perbankan konvensional, seperti adanya jaminan, ataupun surat pengikatan lainnya. Walaupun mereka beralasan untuk kehatihatian. Kurang memadainya fasilitas juga menjadi kelemahan produk ini, karena mereka tidak bisa menyetorkan angsuran secara on line, tetapi harus datang langsung ke kantor dan nasabah terkadang butuh waktu luang untuk itu. Bagi nasabah yang jarang dirumah juga terkadang kurang begitu terbantu dengan adanya sistem jemput bola. Kelemahan dari promosi yang digunakan oleh Warung Mikro BSM KC. Kendal yaitu masih menggunakan promosipromosi yang yang sudah dipakai oleh perbankan-perbankan lain, terdapat hal yang kurang jelas sehingga menjadikan nasabah salah paham dan kecewa dengan apa yang dipromosikan. 


\section{KESIMPULAN}

Strategi Pemasaran Warung Mikro BSM KC. Kendal strategi pemasaran untuk meningkatkan kesejahteraan masyarakat yaitu dengan pendekatan teori bauran pemasaran (Marketing Mix) antara lain dengan strategi produk, harga, tempat, dan promosi. Berdasarkan hasil penelitian yang dilakukan penulis, bahwa strategi pemasaran yang dilakukan berimplikasi positif terhadap kemajuan usaha para nasabahnya. Adapun keunggulan produk yang dimiliki antara lain berprinsip dan akad sesuai dengan syari'ah, limit pembiayaan sesuai segemen mikro, proses pengajuan pembiayaan relatif mudah dan cepat, angsuran ringan dan tetap hingga jatuh tempo, program pelatihan dan pendampingan usaha bagi UMK, menggunakan pendekatan kolektif/perseorangan dan sistem jemput bola dan terletak didaerah yang relatif dekat dengan lokasi usaha segmen mikro. Sedangkan kelemahan pembiayaan Warung Mikro BSM antara lain; kurangnya pegawai yang benar-benar memahami dan menguasai transaksi syari'ah, fasilitas yang kurang canggih dan promosi masih monoton sehingga kurang efisien. 


\section{DAFTAR PUSTAKA}

Abu Zakaria, Riyadus sảlihỉn, Achmad Sunaryo, Terjemahan Riyadus sảlihỉn, Jakarta: Pustaka Amani, 1999

Amin Abdullah, Strategi Pemasaran Asuransi Syariah, Jakarta: PT. Grasindo, 2007

Bashu swasta dhammesta, Manajemen Pemasaran: Analisa Perilaku Konsumen, Yogyakarta: BPFE, 2000

Crown Dirgantoro, Manajemen Stratejik, Jakarta: PT Grasindo, 2001

David Hunger dan Thomas Wheelen, Manajemen Strategis, Yogyakarta: Penerbit Andi, 2003

Departemen Agama RI, Al Qur'an dan Tafsirnya:Edisi Yang Disempurnakan, Jakarta: Departemen Agama RI, Cet. Ke-3, 2009

Departemen Pendidikan Nasional, Kamus Besar Bahasa Indonesia: Pusat Bahasa, Jakarta: Gramedia Pustaka Utama, 2012

Faisal Akbar, Strategi Pemasaran BMT Al Ikhlas Yogyakarta, Skripsi Ekonomi Islam, Yogyakarta, Perpustakaan UII, 2010

Hamzah Ya'kub, Kode Etik Dagang Menurut Islam, Bandung: CV. Diponegoro, Cet. Pertama, 1984

Hasil pengajuan Kuesioner kepada nasabah pada hari senin-jum'at, 20-24 Mei 2013

Hasil wawancara dengan Bapak Hari Novianto Kepala Warung mikro Bank Syari'ah Mandiri, Oktober 2012-Mei 2013

Ibnu Hajar al-asqalani, Bulugul marảm min adillah al-ahkảm, Al-Hafidz Abdul Rosyad Siddiq, Terjemahan Lengkap Bulugul marảm, Jakarta: Akbar Media Eka Sarana, 2009

Kashmir, Kewirausahaan, Jakarta: PT Raja Grafindo, 2006

Kasmir, Bank dan Lembaga Keuangan Lainnya, Jakarta: Raja Grafindo Persada, 2002

M. Abdul Mujieb, Kamus Istilah fiqh, Jakarta: PT. Pustaka Firdaus, Cet. 1, 2001

M. Nazir, Metode Penelitian, Jakarta: Ghalia Indonesia, 1988

Mudrajat Kuncoro, Manajemen Perbankan, Teori dan Aplikasi, Yogyakarta: BPFE, 2002

Phillip Kot ${ }^{\dagger}$ ler, Manajemen Pemasaran Analisis, Perencanaan, Implementasi, dan Kontrol, Jakarta : Prehallindo, 2002

Suryana, Kewirausahaan, Jakarta: PT Salemba Emban Patria, 2001 
Jurnal Iqtisad: Reconstruction of Justice and Welfare for Indonesia - Vol. 6, No 2 (2019) P-ISSN: 2303-3223; E-ISSN: 2621-640X

Strategi Pemasaran Pembiayaan....

W.J.S Poerwadarminta, Kamus Umum Bahasa Indonesia, cet. 6, Jakarta: Balai pustaka, 1983

www. syari'ahmandiri.co.id, Diakses pada tanggal 5 Oktober 2012 